\title{
Effects of 7 days of arginine-alpha-ketoglutarate supplementation using NO2 Platinum on brachial artery blood flow and the levels of plasma L-arginine, nitric oxide, and eNOS after resistance exercise
}

\author{
Jeremy Reid*, Garson Skelton, Mandy Clark, Anthony Boucher, Darryn S Willoughby \\ From International Society of Sports Nutrition; 7th Annual ISSN Conference and Expo \\ Clearwater Beach, FL, USA. 24-26 June 2010
}

\section{Background}

Arginine-alpha-ketoglutarate supplements are alleged to increase nitric oxide production, thereby resulting in vasodilation, which will increase oxygen and nutrient delivery to muscles which during resistance exercise and facilitate muscle hypertrophy. Therefore, the purpose of this study was to determine the effects of 7 days arginine-alpha-ketoglutarate supplementation using NO2 Platinum on arterial blood flow and the levels of circulating L-arginine, nitric oxide, and eNOS after resistance exercise.

\section{Methods}

In a randomized, double-blind format 24 physicallyactive males, ages $18-25$, underwent 7 days of supplementation with 12 caplets daily $(1,200 \mathrm{mg})$ of either NO2 Platinum $(n=12)$ or placebo $(n=12)$. Before and after the supplementation period, a resistance exercise session was performed involving 3 sets of 15 repetitions with $70 \%-75 \%$ of the $1-\mathrm{RM}$. Immediately prior to, immediately after, and $30 \mathrm{~min}$ after each exercise session brachial artery blood flow was determined and venous blood was obtained. Blood samples were used to determine the levels of plasma L-arginine, nitric oxide, and eNOS. Data was analyzed with a 3way (group $\mathrm{x}$ test $\mathrm{x}$ time) ANOVA $(\mathrm{p}<0.05)$. Plasma
L-arginine, however, was analyzed with a 2-way (group $\mathrm{x}$ time) ANOVA $(\mathrm{p}<0.05)$.

\section{Results}

From the pre-exercise blood samples at each exercise session, L-argninine decreased $0.89 \%$ in the placebo group after supplementation, whereas the NO2 group significantly increased $84.67 \%(\mathrm{p}=0.001)$. Brachial artery blood flow was significantly increased in both groups $(\mathrm{p}=0.001)$ immediately post-exercise, but was not different between groups. Nitric oxide was shown to significantly increase in both groups $(\mathrm{p}=0.001)$ immediately post and at $30 \mathrm{~min}$ post-exercise, but was not different between groups. eNOS was significantly increased in both groups $(\mathrm{p}=0.028)$ immediately post and at $30 \mathrm{~min}$ post-exercise $(\mathrm{p}=0.004)$, but was not different between groups.

\section{Conclusion}

Collectively, these results suggest that NO2 Platinum effectively increased plasma L-arginine levels; however, the effects observed in brachial artery blood flow and serum nitric oxide and eNOS were attributed to resistance exercise rather than NO2 Platinum. 


\section{Acknowledgements}

The authors would like to thank all of the participants for their involvement

in the study. This study was supported by funding from the Exercise and

Biochemical Nutrition Laboratory at Baylor University.

Published: 15 September 2010

doi:10.1186/1550-2783-7-S1-P22

Cite this article as: Reid et al:: Effects of 7 days of arginine-alpha-

ketoglutarate supplementation using NO2 Platinum on brachial artery

blood flow and the levels of plasma L-arginine, nitric oxide, and eNOS

after resistance exercise. Journal of the International Society of Sports

Nutrition 2010 7(Suppl 1):P22.

Submit your next manuscript to BioMed Central and take full advantage of:

- Convenient online submission

- Thorough peer review

- No space constraints or color figure charges

- Immediate publication on acceptance

- Inclusion in PubMed, CAS, Scopus and Google Scholar

- Research which is freely available for redistribution

Submit your manuscript at www.biomedcentral.com/submit 